\title{
Wastewater treatment using microalgae: how realistic a contribution might it be to significant urban wastewater treatment?
}

Acién Fernández F.G., Gómez-Serrano C., Morales-Amaral M.M., Fernández Sevilla J.M., and Molina Grima E.

Department of Chemical Engineering, University of Almeria, 04120, Almería, Spain

Author for correspondence:

F. Gabriel Acién Fernández

Department of Chemical Engineering, University of Almeria

La Cañada de San Urbano, Almería 04120, Spain

Telephone: +34950 015443; fax:+34950 015484; e-mail:facien@ual.es

Running title: wastewater treatment with microalgae

Keywords: microalgae, wastewater, nutrient recovery, photosynthetic efficiency, photobioreactors 


\begin{abstract}
Microalgae have been proposed as an option for wastewater treatment since the 1960's but still this technology has not been expanded to an industrial scale. In this paper, the major factors limiting the performance of these systems are analysed. The composition of the wastewater is highly relevant, and especially the presence of pollutants such as heavy metals and emerging compounds. Biological and engineering aspects are also critical and have to be improved to at least approximate the performance of conventional systems, not just in terms of capacity and efficiency but also in terms of robustness. Finally, the harvesting of the biomass and its processing into valuable products poses a challenge; yet at the same time, an opportunity exists to increase economic profitability. Land requirement is a major bottleneck that can be ameliorated by improving the system's photosynthetic efficiency. Land requirement has a significant impact on the economic balance but the profits from the biomass produced can enhance these systems' reliability, especially in small cities.
\end{abstract}




\section{Introduction}

Conventional wastewater treatment is based on sequential aerobic/anaerobic processes that convert contaminants contained in wastewater into inert compounds which allows the safe disposal or reuse of the water. These conventional processes provide satisfactory levels of carbon, nitrogen and phosphorous removal but at the expense of high energy consumption and nutrient loss. Moreover, conventional wastewater treatments are complex, requiring qualified personnel to manage them adequately. They also have a significant environmental impact due to the emission of greenhouse gases $\left(\mathrm{CO}_{2}, \mathrm{CH}_{4}, \mathrm{~N}_{2} \mathrm{O}\right.$, etc.). Data from Aqualia, the third largest wastewater treatment company in Europe, which processes up to $500 \mathrm{Mm}^{3} /$ year of urban wastewater, indicate that conventional wastewater treatment involves an average energy consumption of 0.5 $\mathrm{kWh} / \mathrm{m}^{3}$, costing $0.2 € / \mathrm{m}^{3}-50 \%$ of the cost corresponding to the energy consumed. This company alone removes up to $25,000 \mathrm{t} /$ year of nitrogen and $5.000 \mathrm{t} /$ year of phosphorous to the environment. Utilizing this large amount of nitrogen and phosphorous to produce microalgae would allow the production of up to $0.5 \mathrm{Mt} / \mathrm{year}$ of biomass, twenty-times higher than the present worldwide production of microalgae biomass. For this reason, it has been reported that utilizing microalgae for wastewater treatment to reduce energy consumption, while at the same time recycling nitrogen and phosphorous, presents substantial environmental benefits. These derive from avoiding the use of mineral sources in the microalgae production process and the depletion of phosphorous reservoirs, yet ensuring that large amounts of valuable biomass are produced (Olguín et al., 2012).

Wastewater can be used to produce microalgae and, at the same time, be cleaned by it; this is because the wastewater's composition is quite similar to the culture media usually utilized to produce Consequently, wastewater contains carbon, nitrogen, phosphorus and other minor components required for microalgal growth although some other undesirable compounds such as heavy metals and emerging pollutants can also be found (Morales-Amaral et al., 2015a; Muñoz et al., 2006). The utilization of microalgae for wastewater treatment was first reported by Oswald in 1960 but has recently been reviewed (Mehrabadi et al., 2015; Muñoz et al., 2006; Olguín et al., 2012; Park and Craggs, 2010). However, there is little industrial development of this technology, with only a few small-scale facilities in existence. The reason this technology has not been 
applied at the large scale is because it is not as efficient as conventional processes. To be competitive, microalgal-based processes must be improved: (i) to increase the robustness of the process whatever the environmental conditions, (ii) to reduce the present hydraulic retention time used, of around 7-11 days, to values approximating the 0.3 days accomplished in conventional processes, (iii) to reduce the power consumption below $0.5 \mathrm{kWh} / \mathrm{m}^{3}$ of wastewater, and (iv) to ensure that the quality of the released water complies with regulations. In order to achieve these objectives, both the biological and the engineering aspects of the process must be reconsidered. Optimal strategies to maximize the system's efficiency must be implemented, and the developed processes' performance must be validated under real conditions over a long period. In this work, we have performed a critical analysis of the latest results available in this field to identify the major obstacles hindering the expansion of microalgae-based processes for wastewater treatment.

\section{Wastewater composition}

The composition of wastewater varies mainly as a function of location and the predominant activities in the surrounding area (agriculture, industry, farms, etc.). Moreover, inside the wastewater treatment plant, three different types of wastewater are also identified: (i) after primary treatment when the solids and fats are removed, (ii) after secondary treatment once most of the organic matter is removed, and (iii) the centrate from anaerobic digestion, which contains a high contaminant concentration (Figure 1). The main contaminants found in wastewater include organic matter (COD), nitrogen and phosphorus, as well as iron and manganese, etc., all of which are required to produce microalgae (Morales-Amaral et al., 2015a). Additionally, other pollutants such as heavy metals and emerging compounds (cosmetics, pharmaceuticals, surfactants, etc.) can be found in wastewater, any of which can be toxic to microalgae (Muñoz et al., 2006). The system's performance can also be significantly influenced by the presence of suspended solids and the colour of the water (Marcilhac et al., 2014). When comparing the composition of different wastewater types with the standard culture medium, one can conclude that they are relatively similar although certain differences do exist (Table 1). The culture medium needs to contain all of the nutrients required by the microalgae biomass. Considering that the microalgae biomass $\mathrm{C} / \mathrm{N} / \mathrm{P}$ is $100 / 14 / 2$, one observes that only primary treatment wastewater is close to this value, the 
others having excessive amounts of $\mathrm{N}$ and $\mathrm{P}$, or a limitation of $\mathrm{C}$. This simple analysis demonstrates that microalgae grown in these culture media are carbon limited, needing an additional carbon supply in the form of $\mathrm{CO}_{2}$ or bicarbonate to allow for the complete assimilation of $\mathrm{N}$ and $\mathrm{P}$ contained within the culture medium. Moreover, even if the wastewater composition does not necessitate $\mathrm{CO}_{2}$ injection to supply carbon, it is still important to do so in order to control the system's pH. As they grow, microalgae consume carbon and nitrogen from the culture medium, thus modifying the $\mathrm{pH}$, increasing it to values of 10 and above. High $\mathrm{pH}$ values adversely affect both the bacteria and microalgae, limiting their performance and their growth rate, and therefore their capacity to remove contaminants from the medium. The injection of flue gases, or other residual gases, is a good alternative (Park and Craggs, 2010; Posadas et al., 2015); nonetheless, this has to be performed carefully to avoid inefficient $\mathrm{CO}_{2}$ use, leading to subsequent $\mathrm{CO}_{2}$ release into the environment (de Godos et al., 2014). The best strategy for supplying $\mathrm{CO}_{2}$ into microalgae cultures is by on-demand injection of flue gases, the higher the flue gas $\mathrm{CO}_{2}$ content, the lower the gas flow required; indeed, no adverse effects were observed in microalgae cultures even when using pure $\mathrm{CO}_{2}$ (Duarte-Santos et al., 2016).

With regard to nitrogen, it is mainly found as ammonium in wastewater, which can be toxic to microalgae at concentrations exceeding $100 \mathrm{mg} \cdot \mathrm{l}^{-1}$ (Collos and Harrison, 2014). Values above this limit are commonly found in centrate from anaerobic digestion, making it necessary to dilute this effluent prior to use as the culture medium inside the reactor (Morales-Amaral et al., 2015a). Microalgae are especially sensitive to the combined effects of high ammonium concentrations and high $\mathrm{pH}$ values because above $\mathrm{pH}$ 9, most of the ammonium is in the form of ammonia, and $\mathrm{NH}_{3}$ uncouples the electron transport in photosystem II, competing with $\mathrm{H}_{2} \mathrm{O}$ in the oxidation reactions thus leading to $\mathrm{O}_{2}$ generation. For instance, C. sorokiniana was completely inhibited at a total $\mathrm{NH}_{3} / \mathrm{NH}^{4+}$ concentration of $270 \mathrm{mg} \mathrm{l}^{-1}$ when the $\mathrm{pH}$ was 8.7 (Muñoz et al., 2005). With regard to phosphorus, this is essential for algal growth as it is involved in many cellular processes even though it makes up less than $1 \%$ of the biomass. The N/P ratio in wastewater is critical because excess nitrogen cannot be removed if the phosphorus content is insufficient to allow it; in fact, it is sometimes necessary to supply additional phosphorus to reduce the nitrogen level below the release limits (Ledda et al., 2015; Sepúlveda et al., 2015). 
Lastly, concentrations of heavy metals and emerging compounds found in wastewater are usually so low that there is no observable effect on the system's performance. However, even at concentrations as low as $2 \mathrm{mg} \cdot \mathrm{l}^{-1}$, heavy metals such as copper can impede photosynthesis and modify the microalgae cell walls (Muñoz et al., 2006). Regarding emerging compounds, microalgae are especially sensitive to these pollutants, with phenanthrene concentrations of $10 \mathrm{mg} \cdot 1^{-1}$ inhibiting the growth of Chlorella sorokiniana (Borde et al., 2003). Moreover, wastewater contains pathogens and other microorganisms that can interfere with the treatment process.

Knowing the exact composition of the wastewater to be treated is mandatory for adequate process design, especially to determine if additional carbon, nitrogen or phosphorus needs to be added, as well as the overall flow that can be treated according to the system's biological/engineering capacity. The direct use of primary settled wastewater is usually performed as it is not necessary to modify its characteristics (dilution, additional treatments). Furthermore, wastewater from the secondary treatment can be treated with microalgae (acting as the tertiary treatment) for polishing, and for removing any remaining nitrogen and phosphorous from the secondary treatment. In this case, because of the low nutrient concentration in this type of wastewater, the flow can be increased using membranes to ensure cellular retention as employed in typical membrane bioreactors (MBR). With regard to the utilization of centrate from the anaerobic digestion of activated sludge, this effluent contains up to $1000 \mathrm{mgN} \cdot \mathrm{l}^{-1}$ and 30 $\mathrm{mgP} \cdot \mathrm{l}^{-1}$, and it requires prior dilution to avoid inhibition caused by an excess of ammonium, thus lowering the net flow that can be treated. Inadequate flow, or composition, reduces the reliability of the entire process. The behaviour of pathogens and micropollutants, such as heavy metals and emerging compounds, must be analysed in each case.

\section{Biological aspects}

In reality, microalgal wastewater treatment is performed by consortia of microalgae and bacteria, as it is not reasonable to use pure cultures. Moreover, because it makes no sense to sterilize wastewater prior to treatment, the final population mostly varies as a function of the environmental and operational conditions (although specific strains can be inoculated), especially the composition of wastewater being processed (Posadas et al., 2014). With respect to the microalgae, information is scarce regarding the variation 
in population as a function of culture conditions. Prevailing strains include those that are fast growing and tolerant to the irradiance and temperature values found at the location where the reactor is installed. Strains such as Oscillatoria, Scenedesmus, Chlorella and Nitzchia have been ranked as the most pollution-tolerant microalgae in wastewater treatment systems (Palmer, 1969). A recently performed in-depth analysis on microalgae based on wastewater composition confirmed these figures (Fouilland et al., 2014). Surprisingly, the cultures are generally dominated by a single strain, making up to $90 \%$ of the total microalgae population, although more complex populations can also be found (Morales-Amaral et al., 2015a; Park et al., 2011; Posadas et al., 2014). Various methods have been reported to "control" the strains prevailing in these systems, namely the manipulation of culture conditions or the recirculation of harvested biomass; however, their final impact on improving system performance has not been clearly demonstrated (Park et al., 2011). With regard to bacteria, their presence is necessary, and indeed beneficial, to microalgae growth, with a great diversity of bacteria living symbiotically alongside the microalgae. Little information is available regarding the bacterial populations present in these systems. When using digestate, the bacterial community was dominated by $\gamma$-proteobacteria: mainly Pseudomonas stuzeri and $\alpha$ proteobacteria related to Labrenia, Hoefflea and Sulfitobacter (Vasseur et al., 2012); whereas when using pig manure, most of the species $(\approx 54 \%)$ belonged to Verrucomicrobium (a ubiquitous phylum of aerobic bacteria commonly found in eutrophic environments), Firmicutes and Proteobacteria (Gammaproteobacteria) (Ferrero et al., 2012).

As a simplified scheme of the process, the bacterial cells are responsible for the oxidation of organic matter to inorganic compounds $\left(\mathrm{CO}_{2}, \mathrm{NH}_{4}^{+}, \mathrm{PO}_{4}^{-3}\right)$, whereas the microalgal cells perform photosynthesis using solar light as the driver producing oxygen $\left(\mathrm{O}_{2}\right)$ and consuming the inorganic compounds thus producing biomass (Figure 2A). In this simplified scheme, the oxygen produced by the microalgae is used by the bacteria whereas the $\mathrm{CO}_{2}$ released by the bacteria is used by the microalgae (Muñoz et al., 2006). However, the reality is far more complex, with different microalgal and bacterial metabolisms taking place at the same time (Table 2Table 2). The main biological metabolisms occurring include microalgae-based phenomena such as the phototrophic growth of the photosynthetic biomass and hydroxyl ions released by nitrate assimilation with subsequent reduction to ammonium. The mixotrophic/heterotrophic growth of microalgae can also take place although this is only capable of uptaking small organic 
molecules, such as short-chain carbohydrates, meaning its contribution is minimal. Conversely, bacteria-based phenomena include the aerobic growth of heterotrophic biomass, denitrification by the anoxic growth of heterotrophic biomass, nitrification by the aerobic growth of autotrophic biomass, as well as biomass decay. Other additional processes take places such as bicarbonate reactions, ammonification of soluble organic nitrogen, and hydrolysis of organic matter, etc. Approximate modelling of these complex systems has recently been carried out although no robust models are yet available (Broekhuizen et al., 2012; Karya et al., 2013).

According to the simple scheme proposed, equilibrium would be expected between the microalgae and the bacteria, perhaps not in cell numbers or dry weight but in the main metabolisms such as $\mathrm{O}_{2} / \mathrm{CO}_{2}$ production/consumption or COD/N-P degradation/assimilation. However, data from batch cultures performed in microalgae cultures using centrate as the nutrient source show that the carbon content corresponding to microalgae is always larger than that corresponding to bacteria, by a ratio of approximately 10-20 (Vasseur et al., 2012). Moreover, the carbon content corresponding to microalgae increases throughout the batch culture whereas the carbon content corresponding to bacteria only increases in the first 2-3 days, then decreases below $10 \mathrm{mg} \cdot \mathrm{l}^{-1}$ (Vasseur et al., 2012). With regard to metabolisms, the amount of $\mathrm{O}_{2}$ produced by photosynthesis performed by microalgae must be equal to the oxygen required by the bacteria to oxidize the organic matter; the dissolved oxygen concentration must remain constant. However, this does not occur - instead, the dissolved oxygen concentration in the microalgae cultures used to treat the wastewater varies in relation to the solar radiation, from 50-80 \%Sat (4-6 mg $\left.\cdot 1^{-1}\right)$ at night to 200$250 \%$ Sat $\left(16-20 \mathrm{mg} \cdot \mathrm{l}^{-1}\right)$ at noon, as a function of operating and environmental conditions (Figure 3). Oxygen is produced from the photosynthesis carried out by the microalgae whereas it is consumed by the bacteria in heterotrophic and nitrification processes. Moreover, maintaining high dissolved oxygen levels reduces the denitrification process performance. At the same time, the $\mathrm{pH}$ also changes throughout the solar period, increasing up to $\mathrm{pH} 9.0$ if $\mathrm{CO}_{2}$ is not supplied. The $\mathrm{pH}$ increases as a result of $\mathrm{CO}_{2}$ and $\mathrm{NO}_{3}{ }^{-}$uptake by the microalgae but then decreases due to $\mathrm{CO}_{2}$ release from heterotrophic bacteria and $\mathrm{H}^{+}$release from additional nitrifying bacteria. The limited data available from real systems indicate that overall system performance mainly agrees with that expected from microalgae-based cultures, with bacteria contributing to the uptake of oxygen and acidification. Additionally, 
photosynthetic/respiration measurements performed in the laboratory demonstrate that the oxygen production rate is much higher than the nitrification or heterotrophic oxygen demand, at least during the daytime (Figure 5).

These figures indicate that the overall simple scheme generally assumed for these systems could not be adequate, the bacterial contribution to the performance of the consortium being minor and the overall performance mainly being determined by the microalgae cells (Figure 2B). According to this scheme, the bacterial population is limited by the amount of organic matter supplied to the system, and because their metabolism is faster than the microalgae's, a low bacterial mass is enough to degrade it to inorganic compounds. Therefore, the limiting step to producing biomass is the microalgae's metabolism, which consumes these inorganic compounds, the amount of oxygen produced in this process being far higher than that required by the low bacterial mass. To adequately design and operate microalgae-based systems for wastewater treatment, it is essential to understand and model these phenomena.

\section{Removal capacity}

According to the new scheme proposed, the performance of microalgae-based processes for wastewater treatment is principally centred on adequate microalgae growth conditions. Bacteria digest the organic matter very rapidly and produce $\mathrm{CO}_{2}, \mathrm{NH}_{4}^{+}$and $\mathrm{PO}_{4}{ }^{-3}$, which then have to be assimilated by the microalgae. If the culture conditions are inadequate for the microalgae, the $\mathrm{CO}_{2}$ is stripped to the air instead of being consumed or stored in the water as bicarbonate buffer. The $\mathrm{NH}_{4}{ }^{+}$can be oxidized to nitrate and then denitrified to $\mathrm{N}_{2}$ as a function of the bacterial metabolism, or directly stripped to the air as $\mathrm{NH}_{3}$ if the $\mathrm{pH}$ is higher than 9 . The $\mathrm{PO}_{4}^{-3}$ can be precipitated under alkaline conditions as calcium salt. To maximize the assimilation of inorganic compounds, the microalgal productivity has to be optimized - the higher the microalgal biomass productivity, the higher the system's nutrient removal capacity (Morales-Amaral et al., 2015a).

Consequently, the reactor's design and operation has to be adequate for the microalgae cells. Traditionally, open raceways or High Rate Algae Ponds (HRAPs) have been used because of their low cost and easy scale up. These reactors are operated at water depths ranging from 20 to $40 \mathrm{~cm}\left(\mathrm{~S} / \mathrm{V}=5.0-2.5 \mathrm{~m}^{-1}\right)$ and hydraulic retention times of between 7 to 10 days with power consumption rates below $1 \mathrm{~W} \cdot \mathrm{m}^{-2}$. Under these conditions, light 
availability for the microalgae cells is low, thus the microalgae's growth and performance is low. Alternative designs can be used which include tubular photobioreactors, flat-panel and thin-layer reactors, amongst others. However, tubular and flat-panel photobioreactors impose high energy consumption rates and are generally disregarded for these sorts of application. Regarding thin-layer reactors, the energy consumption in these systems is lower than $10 \mathrm{~W} \cdot \mathrm{m}^{-2}$. They are operated at a water depth from 0.5 to $5.0 \mathrm{~cm}\left(\mathrm{~S} / \mathrm{V}=200-20 \mathrm{~m}^{-1}\right)$, and have hydraulic retention times from 3 to 5 days. Under these conditions light availability is high; hence the growth and performance of the microalgae cells are similarly high.

A performance comparison of thin-layer and raceway reactors at the pilot scale has recently been reported (Morales-Amaral et al., 2015b). The nitrogen removal efficiency was $96 \%$ and $55 \%$, whereas the phosphorus removal efficiency was $50 \%$ and $10 \%$, respectively. The greater nitrogen removal efficiency, compared to that of phosphorus, was a consequence of the nutrients being in adequate proportions, as previously reported (Olguín et al., 2012). Nutrient removal efficiencies usually vary as a function of operational conditions; thus values of $90 \%$ and $80 \%$ for nitrogen and phosphorus, respectively, were reported using Chlorella in primary-settled sewage wastewater (Lau et al., 2014); whereas phosphorus removal from urban wastewater was $80 \%$ for $C$. vulgaris and $83 \%$ for Scenedesmus obliquus (Ruiz-Marin et al., 2010). With regard to micropollutants, the removal of heavy metals, organic compounds and even pathogens has been demonstrated in microalgae-based processes (Muñoz and Guieysse, 2006). Microalgae can remove heavy metals by biofixation, physical adsorption or precipitation - the last two phenomena being faster. Emerging pollutants, on the other hand, are mainly removed by adsorption or oxidation due to high dissolved oxygen and UV radiation. Lastly, pathogen removal principally comes about as a result of an increase in $\mathrm{pH}$, temperature, UV radiation and/or dissolved oxygen in the effluent (Muñoz and Guieysse, 2006).

Although these values are relevant, the most important criteria are (i) the net removal capacity and (ii) the final outlet concentration of nitrogen and phosphorus - this last factor determining whether it is possible to safely release the water into the environment. Thus the net removal capacity is the most valuable data in analysing treatment system performance. Data showing nitrogen and phosphorus removal capacities up to $38 \mathrm{mgN} \cdot 1^{-1} \cdot$ day $^{-1}$ and $3.9 \mathrm{mgP} \cdot \mathrm{l}^{-1} \cdot$ day $^{-1}$ were obtained using a thin-layer reactor (analogous to the nitrogen and phosphorus coefficient yield determined using a 
standard culture medium) whereas in the raceway reactor, values below $20.0 \mathrm{mgN} \cdot \mathrm{l}^{-}$ ${ }^{1} \cdot$ day $^{-1}$ and $0.4 \mathrm{mgP} \cdot \mathrm{l}^{-1} \cdot$ day $^{-1}$ were obtained (Morales-Amaral et al., 2015a). Moreover, $45 \%$ of nitrogen is lost by stripping in the raceway reactor, whereas with the thin-layer reactor, no relevant nitrogen stripping took place (Morales-Amaral et al., 2015a). These values agree with those previously reported, of $47.5 \mathrm{mgN}^{-1}$ day $^{-1}$ and $3.8 \mathrm{mgP} \mathrm{l}^{-1}$ day $^{-1}$ using Muriellopsis sp., and $27.5 \mathrm{mgN}^{-1}$ day $^{-1}$ and $2.7 \mathrm{mgP}^{-1}$ day $^{-1}$ using $P$. subcapitata (Morales-Amaral et al., 2015b); or $35 \mathrm{mgN}^{-1}$ day $^{-1}$ and $5.7 \mathrm{mgP} \mathrm{l}^{-1}$ day $^{-1}$ for $N$. gaditana (Sepúlveda et al., 2015). A maximum removal of $8.5 \mathrm{mgN}^{-1} \mathrm{day}^{-1}$ was reported using Chlorella (Marcilhac et al., 2014).

When considering only nitrogen removal by assimilation with the microalgal biomass produced, the nitrogen removal capacity is limited by the maximal productivity achievable in outdoor systems, which, in turn, is determined by the solar radiation available. For temperate climates, the maximal mean biomass productivity achievable is $50 \mathrm{~g} \cdot \mathrm{m}^{-2} \cdot$ day $^{-1}$ based on a solar efficiency of $5 \%$; thus, assuming a nitrogen content of $7 \%$ in the biomass, the maximal mean nitrogen removal rate is $3.5 \mathrm{gN} \cdot \mathrm{m}^{-2} \cdot \mathrm{day}^{-1}$. The nitrogen supplied to the system must be lower than this value to ensure a low outlet nitrogen concentration, thus adequate treatment efficiency. The nitrogen supply is a function of the wastewater nitrogen concentration and the hydraulic retention time - the higher the water depth, the higher the reactor volume per land unit and the nitrogen supply (Figure 5). Data show that by decreasing the water depth and the hydraulic retention time, the nitrogen supply values are mostly below the system capacity limit, indicating that the system performance should be adequate under these conditions. However, when operating at a greater water depth, the nitrogen supply is higher than the removal capacity whatever the hydraulic retention time might be, meaning the system overloads. Under such conditions, the microalgae cannot assimilate the total nitrogen supplied so nitrifying and denitrifying phenomena are necessary to remove nitrogen from the wastewater. Only by using low water depths can one ensure sufficient microalgae cell performance to assimilate the nitrogen supplied; for this reason, using photobioreactors with large $\mathrm{S} / \mathrm{V}$ ratios is recommended.

\section{Photobioreactor performance}

The main factors governing the adequate design and performance of the reactor are the system's energy consumption and its capacity to satisfy the microalgae cells' 
requirements (mixing, mass transfer, etc.). Even though an in-depth analysis of photobioreactor design has already been published (Acién Fernández et al., 2013; Posten, 2009), opportunities still exist to improve conventional raceway reactors: optimising the fluid-dynamics to minimize power consumption (Mendoza et al., 2013), designing new propellers to circulate the culture inside the reactor such as the LEAR reactor (patent Aqualia), or by improving the sump configuration to optimize the mass transfer capacity (de Godos et al., 2014). In the case of thin-layer reactors, this design was first proposed in the 70's but is still being scaled-up and optimized (Doucha and Lívanský, 1995). Recently, a $1500 \mathrm{~m}^{2}$ unit has been built and is operated by A4F in Pataias (Portugal).

Whatever the reactor type, two major bottlenecks must be overcome: (i) how to increase solar efficiency and (ii) how to reduce energy consumption. Low photosynthetic efficiency (PE) reduces the capacity for producing biomass from solar energy. Microalgae can conserve a maximum of $9-10 \%$ of solar energy (photosynthetic efficiency) but so far outdoor microalgal production systems rarely exceed $6 \%$ (Carvalho et al., 2006). In raceway reactors, photosynthetic efficiency ranges from 0.5$2.0 \%$, with the biomass productivity obtained ranging from $5-20 \mathrm{~g} \mathrm{~m}^{-2}$ day $^{-1}$ (MoralesAmaral et al., 2015a). In thin-layer reactors, photosynthetic efficiency can be increased by up to $4 \%$, giving biomass productivities of up to $40 \mathrm{~g} \cdot \mathrm{m}^{-2} \cdot$ day $^{-1}$ (Morales-Amaral et al., 2015a); values of up to $7 \%$ have been reported for Chlorella sp. in thin-layer reactors (Doucha and Lívanský, 2006). To achieve such values, it is necessary to correctly optimize the reactor's design and operation, as well as optimize the mass transfer capacity and the light regime to which the cells are exposed inside the reactor. The utilization of low-depth systems enhances the frequency of light/dark exposure (Masojídek et al., 2011).

Regarding power consumption, the final energy consumed per $\mathrm{m}^{3}$ of treated wastewater is a function of the specific power consumption in the reactor and the system's hydraulic retention time (Figure 6). It has been shown that systems with low energy consumption $\left(<2 \mathrm{kWh} \cdot \mathrm{m}^{-3}\right)$ can be operated at high hydraulic retention times $($ HRT $>7$ days); the power consumption per $\mathrm{m}^{3}$ of treated wastewater being lower than in conventional systems $\left(0.5 \mathrm{kWh} \cdot \mathrm{m}^{-3}\right)$. However, systems with high specific energy consumption $\left(>5 \mathrm{kWh} \cdot \mathrm{m}^{-3}\right)$, are obliged to operate at low hydraulic retention times (HRT $<4$ days), approximating the growth capacity of microalgae cells under real conditions. By combining these figures with the previous ones, we have concluded that 
the best scenario to optimize microalgae-based wastewater treatment system performance is to operate low-depth systems $(<0.1 \mathrm{~m})$ at moderate hydraulic retention times (3-5 days) and with moderate specific power consumptions $\left(<2.0 \mathrm{kWh} \cdot \mathrm{m}^{-3}\right)$. The optimization of a photobioreactor's design and operating conditions according to the treated wastewater composition, and the "optimal" consortium to be managed in the process, is still unknown and therefore must be determined to allow the industrial development of these technologies.

\section{Harvesting and final biomass use}

Depending on the photobioreactor type and the culture conditions used during the wastewater treatment, the biomass concentration in the culture can range from 0.5 to 2.0 $\mathrm{g} \cdot 1^{-1}$; values in the 4.0-8.0 $\mathrm{g} \cdot \mathrm{l}^{-1}$ range are only achievable when using thin-layer reactors at really shallow depths. All of the biomass needs to be recovered to comply with regulations concerning released water quality. Given the large water volumes processed in wastewater treatment, only robust, low-cost technologies can be used. Consequently, the methods used in conventional processes can be applied to microalgae biomass with only minor modifications being necessary. Hence, utilizing flocculation and settling/flotation steps is the recommended strategy for producing clean wastewater that meet regulations (Christenson and Sims, 2011). This strategy allow one to concentrate the microalgae biomass in sludge of up to $30-40 \mathrm{~g} \cdot 1^{-1}$, with recoveries higher than $95 \%$. Flocculants that have previously been used in conventional processes (aluminium and iron salts, chitosan, polyelectrolytes, etc.) have demonstrated how useful they are (Granados et al., 2012).

Once the sludge is obtained it must be processed according to its final use. It is important to note that when using microalgae-based processes for wastewater treatment, large amounts of biomass can be produced. Therefore, depending on the nutrient content of the wastewater, up to $1 \mathrm{~kg}$ of biomass can be produced per $\mathrm{m}^{3}$ of wastewater processed - this is five times greater than for sludge produced in conventional processes. From a small population of 10,000 people, up to 1,000 $\mathrm{t}$ of biomass can be produced per year. Because this biomass is produced from wastewater, its applications are limited. The most conventional use is biogas production in conventional anaerobic digesters, which are already used in wastewater treatment plants. Up to $3001_{\mathrm{CH} 4} \cdot \mathrm{kg}_{\mathrm{SSV}}$ can be produced from the anaerobic digestion of microalgae biomass; however, it is usually 
necessary to perform biomass pre-treatments to increase their degradability. Moreover, because of the high $\mathrm{N}$ content of the biomass, co-digestion with additional waste is usually necessary (Heaven et al., 2011; Passos and Ferrer, 2015). Alternatively, the microalgae biomass can be used to produce biofertilizers and biostimulants for agricultural use. A treatment step is necessary to disrupt the biomass, liberate the compounds and stabilize it for commercial application. Enzymatic hydrolysis is one of the processing methods proposed (Romero García et al., 2012) but each company's know-how is highly relevant in this field. Microalgae biomass not only provides nutrients but also phytohormones and growth promoters which increase the biomass's value for agricultural use. Neither biogas production nor biofertilizer/biostimulant production requires the biomass to be dried, although a simple dewatering step might be necessary to fix the biomass concentration in the sludge, thus matching the final biomass concentration required for the downstream process.

Using this biomass for other uses such as animal feed or chemicals, even the production of bioplastics and biofuels, is as yet only a concept. Regulatory and technical problems still exist, thus limiting the utilization of microalgae biomass produced from wastewater. This is a serious obstacle for the expansion of microalgae-based processes because until a clear application exists for the produced biomass, the processes are unsustainable.

\section{Future trends}

Microalgae can be used for various wastewater treatments but, as a technology, they cannot completely substitute conventional processes; although they can be an alternative to supplement conventional processes. Microalgae are highly efficient in removing nitrogen and phosphorus even at very low concentrations, hence they have been successfully used as a tertiary treatment to facilitate compliance with the stricter regulations concerning nitrogen and phosphorus release, while at the same time removing micropollutants and pathogens. Another alternative is to use them in centrate treatment - in wastewater treatment plants, centrate from the anaerobic digestion of activated sludge contains up to $1000 \mathrm{mgN} \cdot \mathrm{l}^{-1}$ and $30 \mathrm{mgP} \cdot \mathrm{l}^{-1}$, its treatment within the wastewater treatment plant is costly and energy consuming. Centrate flow in wastewater treatment plants is not a negligible issue, it accounts for $2 \%$ of the total wastewater flow, which has to be recirculated thus further increasing the cost and energy 
consumption of the wastewater treatment process. For a small conventional plant processing $10,000 \mathrm{~m}^{3} \cdot \mathrm{day}^{-1}$ of wastewater, avoiding the need to recirculate and treat this centrate can mean a reduction in the power consumption of up to $2400 \mathrm{kWh} \cdot \mathrm{day}^{-1}$, resulting in an annual cost reduction of $87.6 \mathrm{k} € \cdot$ year $^{-1}$. Finally, microalgae-based processes can also be used for the direct treatment of wastewater following primary treatment - this consumes less energy and allows nutrients to be recovered; at the same time reducing the pollutant concentration at the outlet below the stricter levels that now exist.

The main drivers for the development of microalgae-based wastewater treatment processes are to reduce greenhouse gas emissions, improve the energy balance of the process, and to recover nutrients. At the same time however, a positive economic balance also has to be demonstrated in order to convince the end users to adopt these technologies; hence the valorisation of the biomass produced is highly relevant. Nevertheless, the technology still has to be improved to approximate conventional processes. Consequently, the major challenges are to improve system stability to avoid crashes and ensure effluent quality, as well as to reduce the cost of the technology by reducing the land required to carry out the process.

In conventional wastewater treatment plants, land requirement is not a major bottleneck given that a surface area of 1 ha is sufficient to treat up to $30,000-50,000$ p.e. (person equivalent). However, in microalgae-based processes, up to 30-50 ha might be needed for the same treatment capacity. This significant land requirement limits the application of these technologies to small towns, from 200 to 15,000 p.e., which often lack efficient wastewater treatment systems. Moreover, for these small towns, the cost of conventional treatment systems is excessive and their complexity so great that often they do not work properly. Microalgae-based processes are much simpler and impose a low CAPEX cost; the maintenance is also easier than in conventional systems due to less machinery required and lower energy consumption (lower OPEX cost). Nonetheless, the technology still has to be improved through increased reliability and a reduction in the land required. Currently, operating systems require a surface area of $\approx 6$ $10 \mathrm{~m}^{2}$ per person equivalent - this value needs to be reduced to $\approx 2-3 \mathrm{~m}^{2}$ per person equivalent. Such systems have to operate all-year round (both in winter and summer) to ensure adequate performance. The best way to do this is to increase the system's photosynthetic efficiency and, therefore, the system's capacity is only limited by the solar radiation availability at the selected location. 


\section{Conclusions}

Microalgae-based wastewater treatment processes are currently possible yet still lack the technological improvements necessary to extend their reach to the industrial scale. The principal obstacle concerning this technology is the large land area requirement. To tackle this, it is essential to gain a better understanding of the process' biological aspects and to improve photobioreactor solar efficiency. At the same time, the entire process must be designed and operated according to the initial wastewater composition, as is the case in conventional activated sludge systems. Using microalgae for wastewater processes offers great advantages related to GHG emission reductions, energy saving and nutrient recovery. Nonetheless, the economic benefits of these technologies still have to be demonstrated on a real scale.

\section{Acknowledgements}

This research was supported by EDARSOL CTQ2014-57293-C3 (Spanish Ministry of Science and Innovation) and the PURALGA RTA2013-0056-C03 (INIA) projects. We are most grateful to the Estación Experimental Las Palmerillas of the Fundación Cajamar for collaborating in this research. This research was supported by the Junta de Andalucía and the Plan Andaluz de Investigación (BIO 173).

\section{References}

Acién Fernández FGG, Fernández Sevilla JMM, Molina Grima E, Fernández FGA, Sevilla JMF, Grima EM, Acién Fernández FGG, Fernández Sevilla JMM, Molina Grima E, Fernández FGA, Sevilla JMF, Grima EM. 2013. Photobioreactors for the production of microalgae. Rev. Environ. Sci. Biotechnol. 12:131-151.

Borde X, Guieysse B, Delgado O, Muoz R, Hatti-Kaul R, Nugier-Chauvin C, Patin H, Mattiasson B. 2003. Synergistic relationships in algal-bacterial microcosms for the treatment of aromatic pollutants. Bioresour. Technol. 86:293-300.

Broekhuizen N, Park JBK, McBride GB, Craggs RJ. 2012. Modification, calibration and verification of the IWA River Water Quality Model to simulate a pilot-scale high rate algal pond. Water Res. 46:2911-2926.

Carvalho AP, Meireles LA, Malcata FX. 2006. Microalgal reactors: A review of enclosed system designs and performances. Biotechnol. Prog. 22:1490-1506.

Christenson L, Sims R. 2011. Production and harvesting of microalgae for wastewater treatment, biofuels, and bioproducts. Biotechnol. Adv. 29:686-702.

Collos Y, Harrison PJ. 2014. Acclimation and toxicity of high ammonium concentrations to unicellular algae. Mar. Pollut. Bull. 80:8-23.

Doucha J, Lívanský K. 1995. Novel outdoor thin-layer high density microalgal culture system: productivity and operation parameters. Arch. Hydrobiol/Algol Stud 
76:129-147.

Doucha J, Lívanský K. 2006. Productivity, CO2/O2 exchange and hydraulics in outdoor open high density microalgal (Chlorella sp.) photobioreactors operated in a Middle and Southern European climate. J. Appl. Phycol. 18:811-826.

Duarte-Santos T, Mendoza-Martín JL, Acién Fernández FG, Molina E, Vieira-Costa JA, Heaven S. 2016. Optimization of carbon dioxide supply in raceway reactors: Influence of carbon dioxide molar fraction and gas flow rate. Bioresour. Technol. 212:72-81.

Ferrero EM, de Godos I, Rodr??guez EM, Garc??a-Encina PA, Mu??oz R, B??cares E. 2012. Molecular characterization of bacterial communities in algal-bacterial photobioreactors treating piggery wastewaters. Ecol. Eng. 40:121-130.

Fouilland E, Vasseur C, Leboulanger C, Le Floc'h E, Carr?? C, Marty B, Steyer J-PP, Sialve B, Floc'h E Le, Carré C, Marty B, Steyer J-PP, Sialve B. 2014. Coupling algal biomass production and anaerobic digestion: Production assessment of some native temperate and tropical microalgae. Biomass and Bioenergy 70:564-569.

de Godos I, Mendoza JLL, Acién FGG, Molina E, Banks CJJ, Heaven S, Rogalla F. 2014. Evaluation of carbon dioxide mass transfer in raceway reactors for microalgae culture using flue gases. Bioresour. Technol. 153:307-314.

Granados MRR, Acién FGG, Gómez C, Fernández-Sevilla JMM, Grima EM, Molina Grima E, Grima EM. 2012. Evaluation of flocculants for the recovery of freshwater microalgae. Bioresour. Technol. 118:102-110.

Heaven S, Milledge J, Zhang Y. 2011. Comments on "Anaerobic digestion of microalgae as a necessary step to make microalgal biodiesel sustainable." Biotechnol. Adv. 29:164-167.

Karya NGAI, van der Steen NP, Lens PNL. 2013. Photo-oxygenation to support nitrification in an algal-bacterial consortium treating artificial wastewater. Bioresour. Technol. 134:244-250.

Lau KY, Pleissner D, Lin CSK. 2014. Recycling of food waste as nutrients in Chlorella vulgaris cultivation. Bioresour. Technol. 170:144-151.

Ledda C, Romero Villegas GI, Adani F, Acién Fernández FG, Molina Grima E. 2015. Utilization of centrate from wastewater treatment for the outdoor production of Nannochloropsis gaditana biomass at pilot-scale. Algal Res. 12:17-25. http://dx.doi.org/10.1016/j.algal.2015.08.002.

Marcilhac C, Sialve B, Pourcher A-MM, Ziebal C, Bernet N, Béline F. 2014. Digestate color and light intensity affect nutrient removal and competition phenomena in a microalgal-bacterial ecosystem. Water Res. 64:278-287.

Masojídek J, Kopecký J, Giannelli L, Torzillo G. 2011. Productivity correlated to photobiochemical performance of Chlorella mass cultures grown outdoors in thinlayer cascades. J. Ind. Microbiol. Biotechnol. 38:307-317.

Mehrabadi A, Craggs R, Farid MM. 2015. Wastewater treatment high rate algal ponds (WWT HRAP) for low-cost biofuel production. Bioresour. Technol. 184:202-214. http://dx.doi.org/10.1016/j.biortech.2014.11.004.

Mendoza JLL, Granados MRR, de Godos I, Acién FGG, Molina E, Banks C, Heaven S, Godos I, Acién FGG, Molina E, Banks C, Heaven S. 2013. Fluid-dynamic characterization of real-scale raceway reactors for microalgae production. Biomass and Bioenergy 54:267-275.

Morales-Amaral MDMDM, Gómez-Serrano C, Acién FGG, Fernández-Sevilla JMM, Molina-Grima E. 2015a. Outdoor production of Scenedesmus sp. in thin-layer and raceway reactors using centrate from anaerobic digestion as the sole nutrient source. Algal Res. 12:99-108. 
Morales-Amaral MMM, Gómez-Serrano C, Acién FGG, Fernández-Sevilla JMM, Molina-Grima E. 2015b. Production of microalgae using centrate from anaerobic digestion as the nutrient source. Algal Res. 9:297-305.

Muñoz R, Guieysse B, Muñoz R, Guieysse B. 2006. Algal-bacterial processes for the treatment of hazardous contaminants: A review. Water Res. 40:2799-2815.

Muñoz R, Jacinto M, Guieysse B, Mattiasson B, Muñoz R, Jacinto M, Guieysse B, Mattiasson B. 2005. Combined carbon and nitrogen removal from acetonitrile using algal-bacterial bioreactors. Appl. Microbiol. Biotechnol. 67:699-707.

Muñoz R, Guieysse B. 2006. Algal-bacterial processes for the treatment of hazardous contaminants: a review. Water Res. 40:2799-815.

http://www.scopus.com/inward/record.url?eid=2-s2.033746605638\&partnerID=tZOtx3y1.

Olguín EJ, Olgu??n EJ, Olguín EJ. 2012. Dual purpose microalgae-bacteria-based systems that treat wastewater and produce biodiesel and chemical products within a Biorefinery. Biotechnol. Adv. 30:1031-1046. http://dx.doi.org/10.1016/j.biotechadv.2012.05.001.

Palmer CM. 1969. A COMPOSITE RATING OF ALGAE TOLERATING ORGANIC POLLUTION2. J. Phycol. 5:78-82. http://dx.doi.org/10.1111/j.15298817.1969.tb02581.x.

Park JBK, Craggs RJ. 2010. Wastewater treatment and algal production in high rate algal ponds with carbon dioxide addition. Vol. 61 633-639 p.

Park JBK, Craggs RJ, Shilton AN. 2011. Recycling algae to improve species control and harvest efficiency from a high rate algal pond. Water Res. 45:6637-6649. http://dx.doi.org/10.1016/j.watres.2011.09.042.

Passos F, Ferrer I. 2015. Influence of hydrothermal pretreatment on microalgal biomass anaerobic digestion and bioenergy production. Water Res. 68:364-373. http://dx.doi.org/10.1016/j.watres.2014.10.015.

Posadas E, García-Encina PA, Domínguez A, Díaz I, Becares E, Blanco S, Muñoz R. 2014. Enclosed tubular and open algal-bacterial biofilm photobioreactors for carbon and nutrient removal from domestic wastewater. Ecol. Eng. 67:156-164.

Posadas E, Morales MDMM del M, Gomez C, Acién FGG, Muñoz R. 2015. Influence of $\mathrm{pH}$ and $\mathrm{CO} 2$ source on the performance of microalgae-based secondary domestic wastewater treatment in outdoors pilot raceways. Chem. Eng. J. 265:239248.

Posten C. 2009. Design principles of photo-bioreactors for cultivation of microalgae. Eng. Life Sci. 9:165-177.

Romero García JM, Acién Fernández FG, Fernández Sevilla JM, García JMR, Fernández FGA, Sevilla JMF, Romero Garc??a JM, Aci??n Fern??ndez FG, Fern??ndez Sevilla JM, García JMR, Fernández FGA, Sevilla JMF. 2012. Development of a process for the production of 1-amino-acids concentrates from microalgae by enzymatic hydrolysis. Bioresour. Technol. 112:164-170.

Ruiz-Marin A, Mendoza-Espinosa LG, Stephenson T. 2010. Growth and nutrient removal in free and immobilized green algae in batch and semi-continuous cultures treating real wastewater. Bioresour. Technol. 101:58-64.

Sepúlveda C, Acién FG, Gómez C, Jiménez-Ruíz N, Riquelme C, Molina-Grima E, Sep??lveda C, Aci??n FG, G??mez C, Jim??nez-Ru??z N, Riquelme C, MolinaGrima E. 2015. Utilization of centrate for the production of the marine microalgae Nannochloropsis gaditana. Algal Res. 9:107-116. http://dx.doi.org/10.1016/j.algal.2015.03.004.

Vasseur C, Bougaran G, Garnier M, Hamelin J, Leboulanger C, Chevanton M Le, 
Mostajir B, Sialve B, Steyer JP, Fouilland E. 2012. Carbon conversion efficiency and population dynamics of a marine algae-bacteria consortium growing on simplified synthetic digestate: First step in a bioprocess coupling algal production and anaerobic digestion. Bioresour. Technol. 119:79-87.

http://dx.doi.org/10.1016/j.biortech.2012.05.128. 
Table 1.- Composition of the wastewater at the different treatment stages in conventional wastewater treatment plants.

\begin{tabular}{|l|r|r|r|r|}
\hline $\begin{array}{l}\text { Conc., } \\
\mathrm{mg} / \mathrm{L}\end{array}$ & Arnon & $\begin{array}{r}\text { 1 Primary } \\
\text { treatment }\end{array}$ & $\begin{array}{r}\text { 2 Secondary } \\
\text { treatment }\end{array}$ & $\begin{array}{r}\text { 3 Centrate from } \\
\text { anaerobic } \\
\text { digestion }\end{array}$ \\
\hline COD & - & 500.0 & 110.0 & 300.0 \\
\hline N-NO3 & 114.0 & 2.4 & 0.0 & 5.3 \\
\hline N-NH4 & 0.0 & 62.6 & 20.8 & 506.5 \\
\hline P-PO4 & 41.0 & 11.3 & 10.0 & 12.0 \\
\hline TKN & 114 & 65 & 20 & 511 \\
\hline TP & 41 & 11 & 10 & 12 \\
\hline TC & 47 & 296 & 82 & 247 \\
\hline C/N/P & $100 / 239 / 86$ & $100 / 21 / 4$ & $100 / 25 / 12$ & $100 / 207 / 5$ \\
\hline
\end{tabular}


Table 2.- Main metabolisms taking place in microalgal-bacterial wastewater treatment processes.

\begin{tabular}{|l|l|l|}
\hline Microalgae-based reactions & & \\
\hline $\mathrm{CO}_{2}+\mathrm{H}_{2} \mathrm{O}+\mathrm{NH}_{4}^{+}+\mathrm{PO}_{4}^{-3} \rightarrow$ Microalgae biomass $+\mathrm{O}_{2}$ & Photosynthesis & \\
\hline $\mathrm{NO}_{3}^{-}+4 \mathrm{H}_{2} \mathrm{O} \rightarrow \mathrm{NH}_{4}^{+}+7 \mathrm{OH}^{-}$ & Nitrate reduction & \\
\hline Bacteria-based reactions & & \\
\hline $\mathrm{COD}+\mathrm{O}_{2}+$ Nutrients $\rightarrow$ Bacterial biomass $+\mathrm{CO}_{2}$ & & \\
\hline $\mathrm{NH}_{4}^{+}+2 \mathrm{O}_{2} \rightarrow \mathrm{NO}_{3}^{-}+2 \mathrm{H}^{+}+\mathrm{H}_{2} \mathrm{O}$ & Nitrification & \\
\hline $8 \mathrm{NO}_{3}^{-}+5 \mathrm{CH}_{3} \mathrm{COOH} \rightarrow 8 \mathrm{HCO}_{3}^{-}+6 \mathrm{H}_{2} \mathrm{O}+2 \mathrm{CO}_{2}+4 \mathrm{~N}_{2}$ & Denitrification & \\
\hline
\end{tabular}




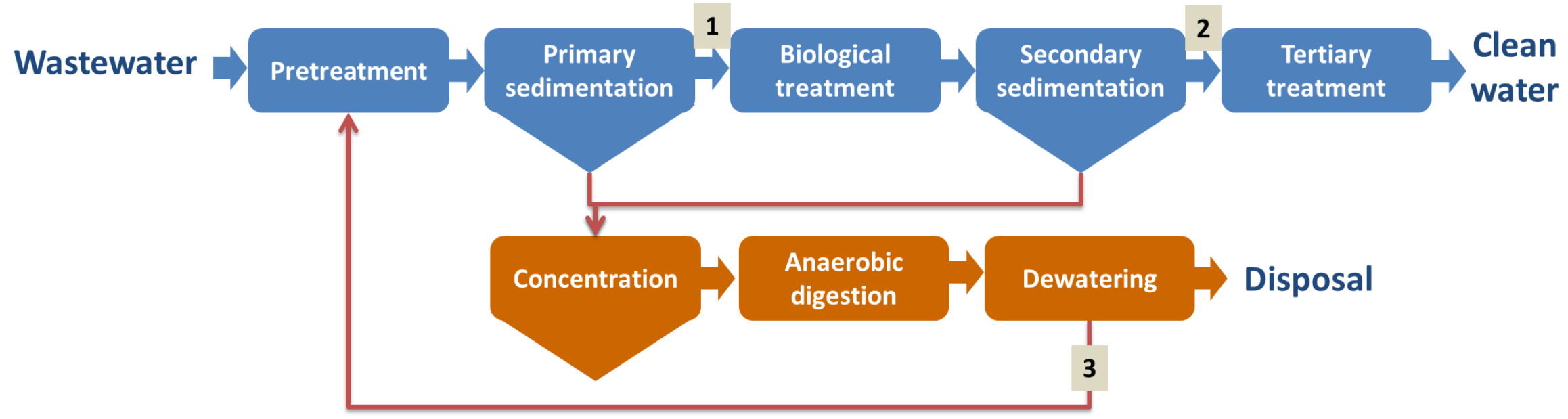

Figure 1.- Simplified scheme of the wastewater treatment process using microalgae-bacteria consortia. 

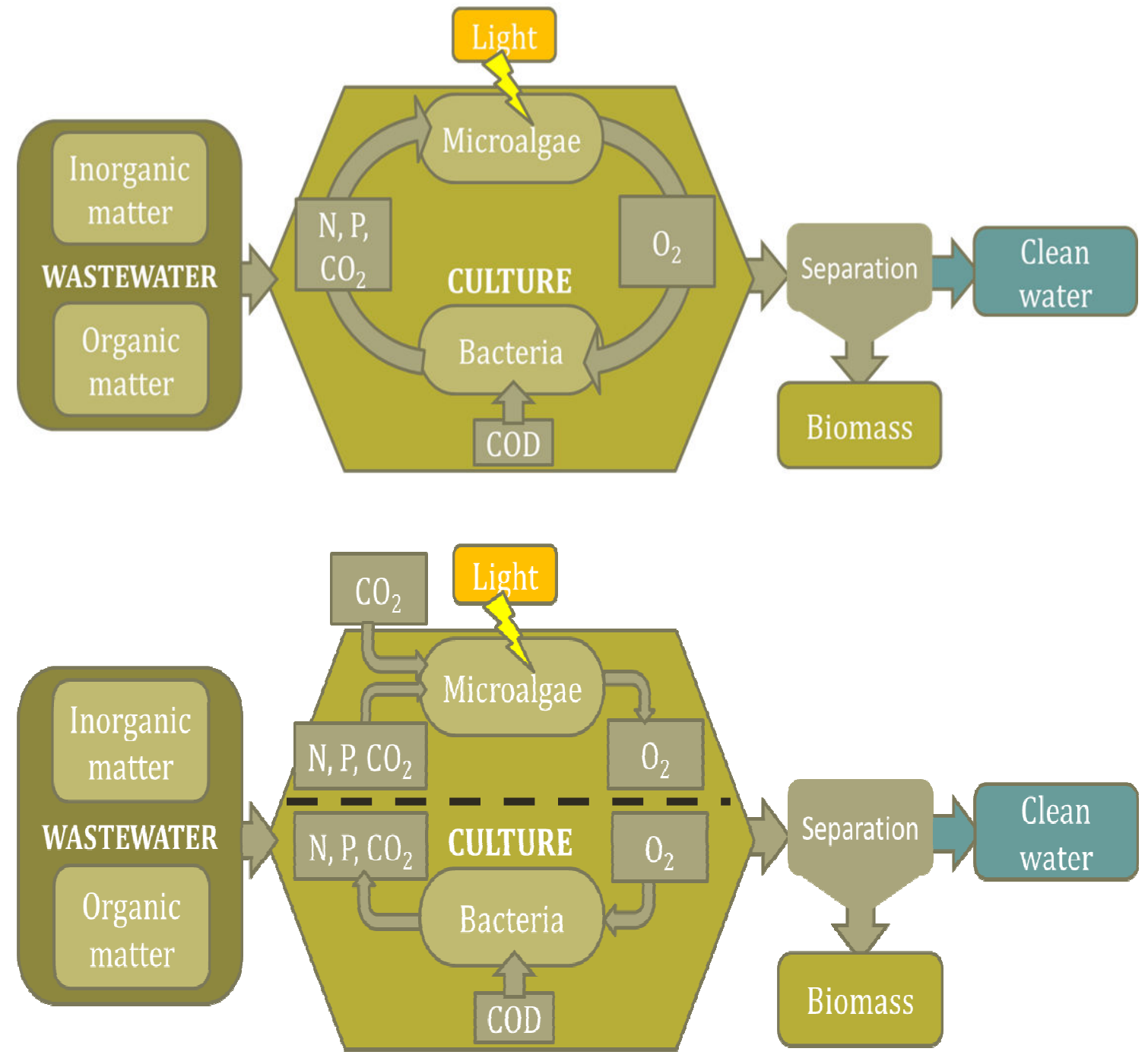

Figure 2.- Simplified scheme of the wastewater treatment process using a microalgaebacteria consortia. A) Scheme considering equilibrium between microalgae and bacteria, B) New proposed scheme considering the microalgae as the main contributor to the system performance. 

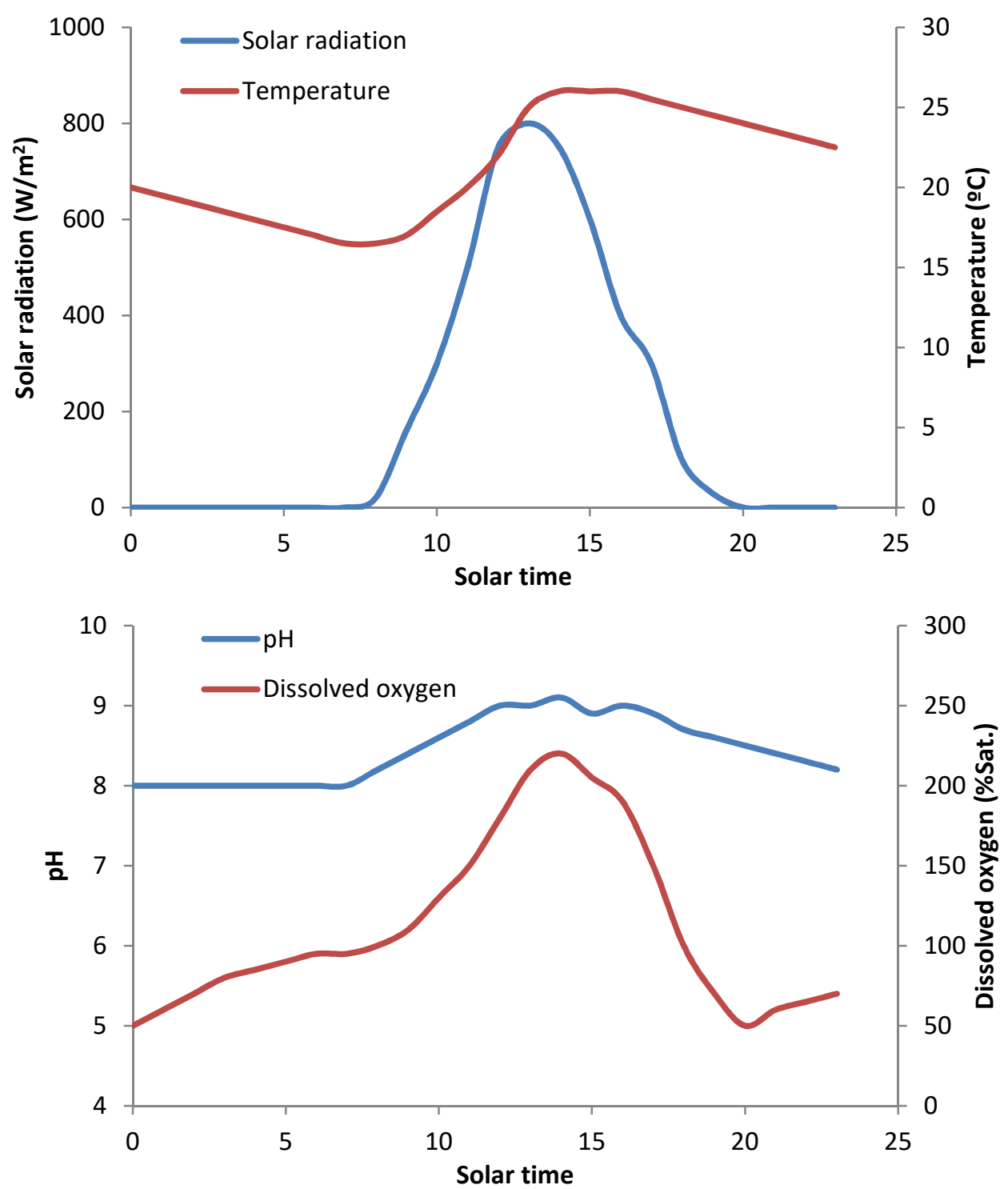

Figure 3.- Daily variation in solar radiation on the reactor surface and the culture parameters (temperature, $\mathrm{pH}$ and dissolved oxygen) as a function of solar time in a raceway reactor operated in continuous mode at 0.3 day $^{-1}$ (HRT $=3$ days) for the treatment of primary wastewater. 


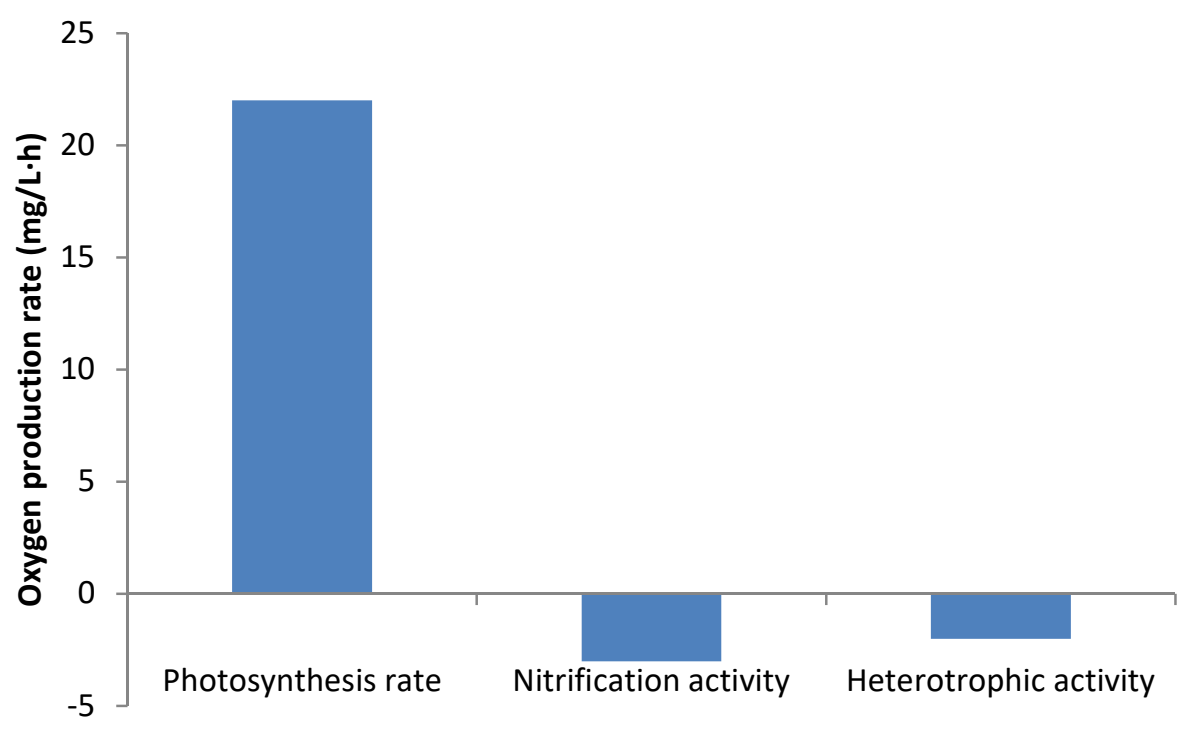

Figure 4.- Oxygen production rate of real samples taken from a raceway reactor operated in continuous mode at 0.3 day $^{-1}$ (HRT $=3$ days) for the treatment of primary wastewater. Measurements were performed after $24 \mathrm{~h}$ starvation under continuous light conditions with a biomass concentration of $1.5 \mathrm{~g} \cdot \mathrm{l}^{-1}$. The photosynthesis rate was measured at an irradiance of $200 \mu \mathrm{E} \cdot \mathrm{m}^{-2} \cdot \mathrm{s}^{-1}$. Nitrification activity and heterotrophic activity were determined in dark conditions while supplying ammonium and acetate, as in the conventional protocol. 


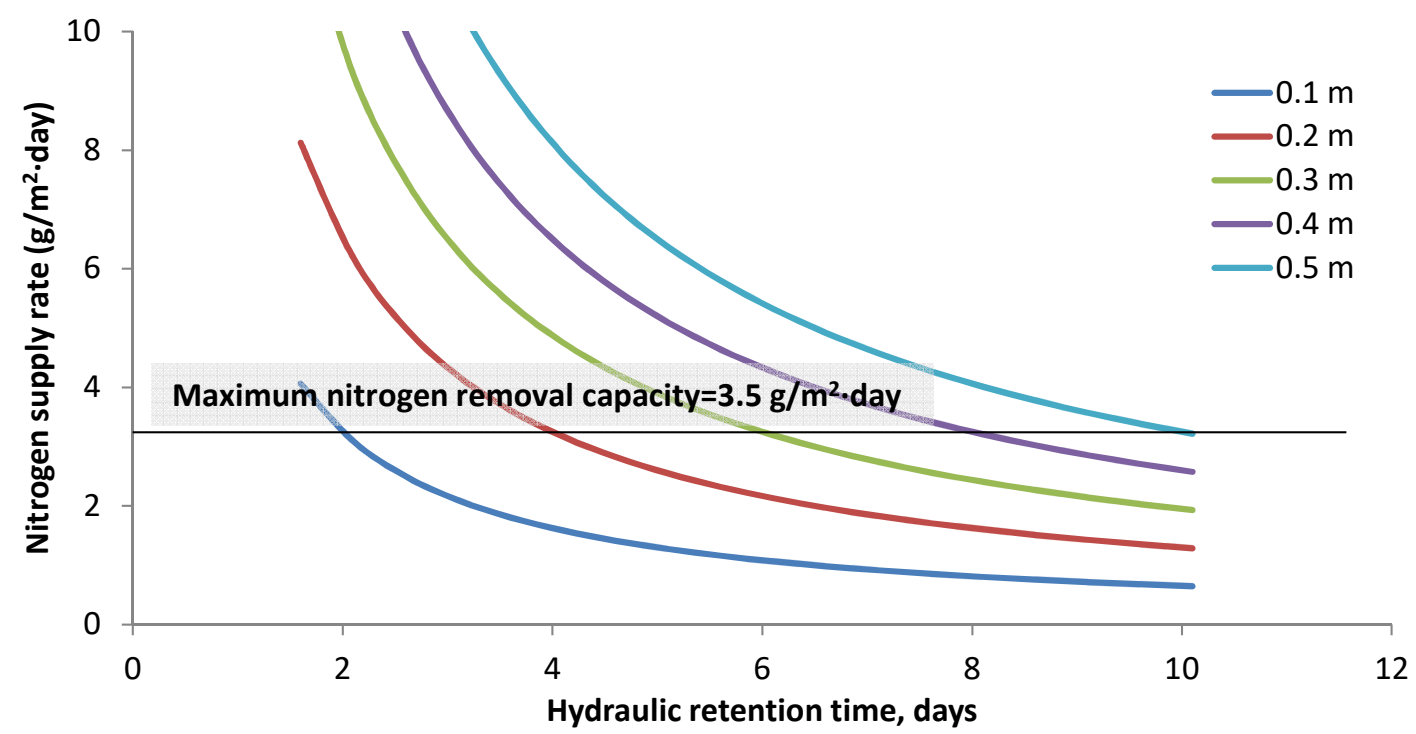

Figure 5.- Variation in the nitrogen supply rate along with the hydraulic retention time in the system as a function of water depth inside the reactor. A maximal value of 3.5 $\mathrm{g} \cdot \mathrm{m}^{-2} \cdot \mathrm{day}^{-1}$ is marked with a continuous line to establish the maximal value possible allowing adequate wastewater treatment. 


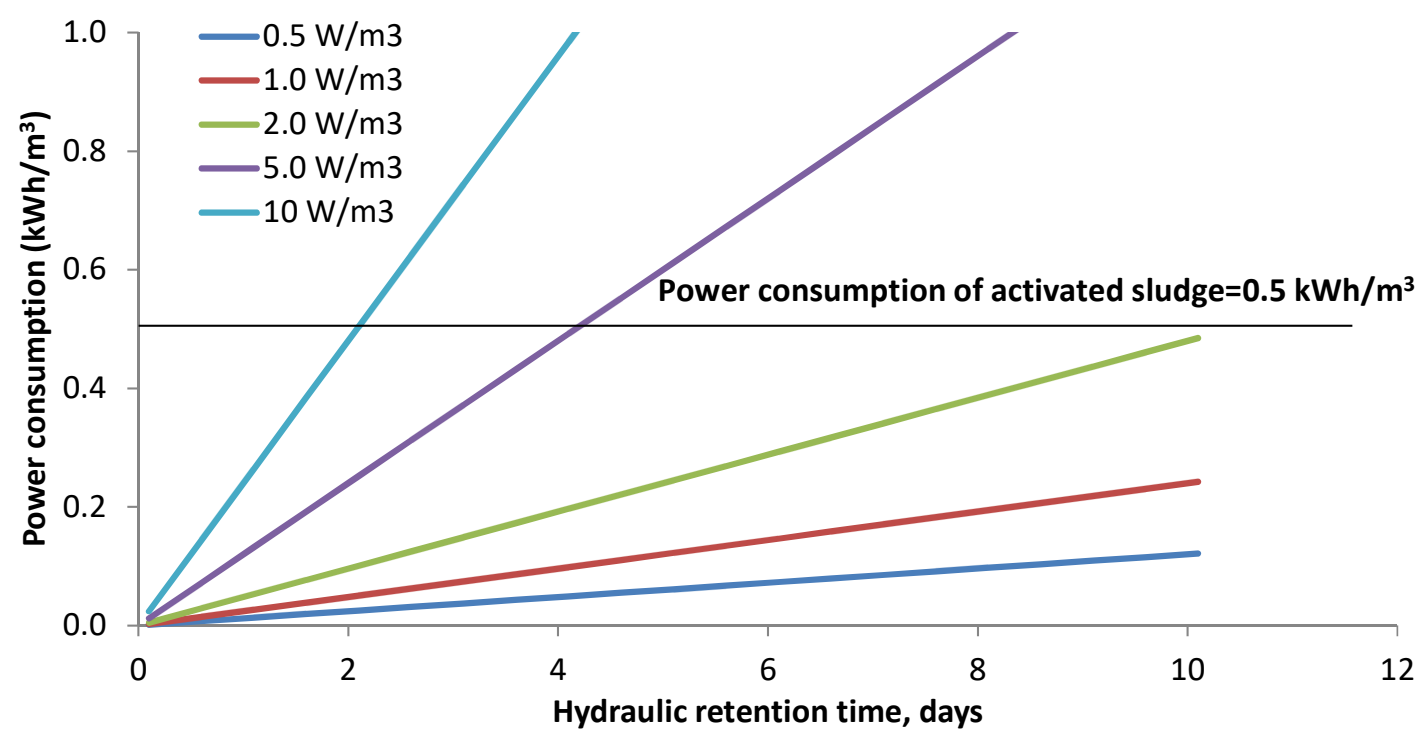

Figure 6.- Variation in the power consumption along with hydraulic retention time as a function of the reactor's specific power consumption. A maximal value corresponding to $0.5 \mathrm{kWh} \cdot \mathrm{m}^{-3}$, as consumed in conventional activated sludge systems, is marked with a continuous line to establish the maximal value possible allowing sustainable wastewater treatment. 